\title{
Monitoring of Excavation Works Using Modern Measuring Technology
}

George POPESCU ${ }^{1}$, Cosmin Alin POPESCU ${ }^{1}$, Mihai HERBEI ${ }^{1 *}$, Lucian DRAGOMIR ${ }^{1}$, Adrian SMULEAC ${ }^{3}$ and Silviu DOROBANTU ${ }^{2}$

${ }^{1}$ Banat's University of Agricultural Sciences and Veterinary Medicine "King Michael I of Romania", Timisoara, ROMANIA

${ }^{2}$ University of Petrosani, ROMANIA

${ }^{3}$ Politehnic University Timisoara, ROMANIA

* corresponding author: mihai.herbei@gmail.com

BulletinUASVM Horticulture 76(2) / 2019

Print ISSN 1843-5254, Electronic ISSN 1843-5394

DOI:10.15835/buasvmcn-hort: 2019.0038

\begin{abstract}
Modern technology plays a fundamental role in the engineering activities undertaken in day-to-day operations, in order to obtain the necessary material for construction or to obtain certain useful materials that are found near the surface. A special contribution of this branch of terrestrial measurements, of the topography, using modern technology, is materialized by specific studies carried out from a preliminary phase of design of the operation and up to the phase in which the perimeter is ecologized. The present article aims to test and evaluate the accuracy of the data for volumetric measurements of exploited material, using modern technology and specialized software based on topographic altitude, with which we will be able to realize the three-dimensional model of the operating perimeter. For this purpose, an exploitation has been chosen on the appropriate surface, materialized through a case study, with reference to the Doman Quarry, Caras Severin, in which we determined the volumes exploited during the activity period.
\end{abstract}

Keywords: engineering measurements, Leica GS08, volumetric calculation

\section{Introduction}

Engineering measurements have an important role in the process of surface mining, supporting the good development of the extraction process, providing indispensable information in the hygienic activities undertaken. The results obtained from the measurement activities in a surface exploitation are quite numerous, we will list only a few of them, the most important ones for the exploitation activity: - realization and updating the topographic situation plans; - making plans and sketches with the working fronts and their modifications; - permanent monitoring and verification of the quarrygeometry; - the volumetric calculation of the material to be exploited or one that has already been exploited (Dima et al, 2014; Păunescu et al, 2017; Sălăgean et al, 2019). New techniques and methods have to be presented in many fields, due to the fact that dynamics are part of our world. The precise acquisition of the measured data regarding the exploitation process that takes place in a career is the key to an efficient and stable maintenance. In other words, this means obtaining an objective evaluation of the working processes, state-of-the-art technologies, up-to-date and the accuracy of the data taken to be reliable. Accurate measurements can be made using GNSS technology. In the last two decades or so, GNSS technologies have become part of the geodesic world. The receivers can be diverse 
and can be used for various purposes. Most often, for engineering tasks, RTK receivers are used (Popescu C. et al, 2016; Voina et al, 2016). The GPS receiver used for the case study is the Leica viva GS08 (Fig. 1) plus with the possibility of real-time measurement with code and phase measurements. The GPS receiver is a dual frequency instrument, with the following technical parameters regarding accuracy, specified by the manufacturer $-5 \mathrm{~mm}$ $+0.5 \mathrm{ppm}$ RMS horizontal and $10 \mathrm{~mm}+0.5 \mathrm{ppm}$ vertical (Cosarca, 2003; Șuba et al, 2017).

\section{Materials and methods}

DOMAN deposit - RESITTA develops in the left slope of the Doman valley, at its confluence with the Stârnic stream at the south and with the Rece stream at the north, at approx. $0.5 \mathrm{~km}$ south-west of the municipality of Resita, having a length of about $850 \mathrm{~m}$ and a width of $550 \mathrm{~m}$. Administratively it belongs to the municipality of Resita (Fig. 2).

Access to the area is via the national road DN58 Resita-Anina, approx. $1.5 \mathrm{~km}$ from the national road the access to the deposit - the quarry being made by an operating road of approx. $600 \mathrm{~m}$.

The area is hilly, with altitudes of up to 400 $\mathrm{m}$, with a difference of level of $120 \mathrm{~m}$, with steep slopes, with inclinations of $40-50^{\circ}$, inclines that lower towards the top, $\left(10-15^{\circ}\right)$. Within the deposit, the land dimensions vary within the limits $+325 \mathrm{~m}$ to $+365 \mathrm{~m}$

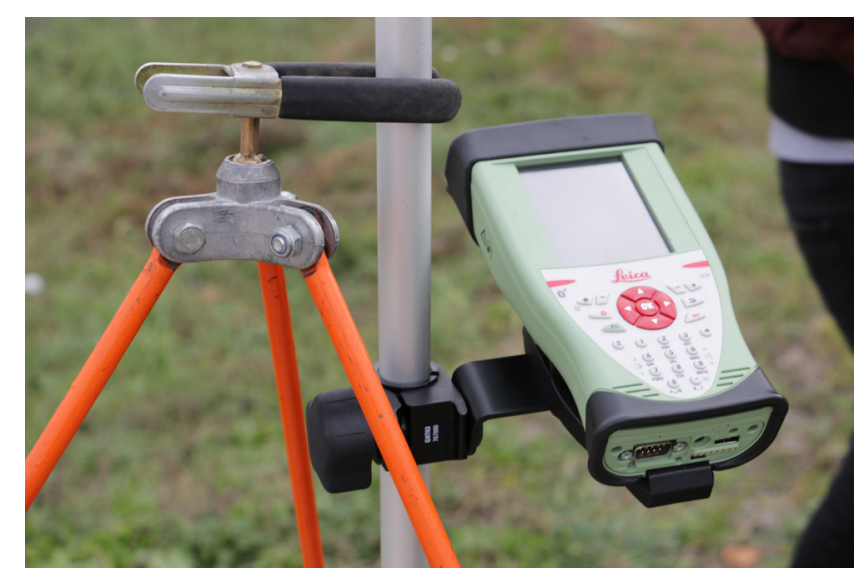

Figure 1. GNSS receiver GPS viva GS08

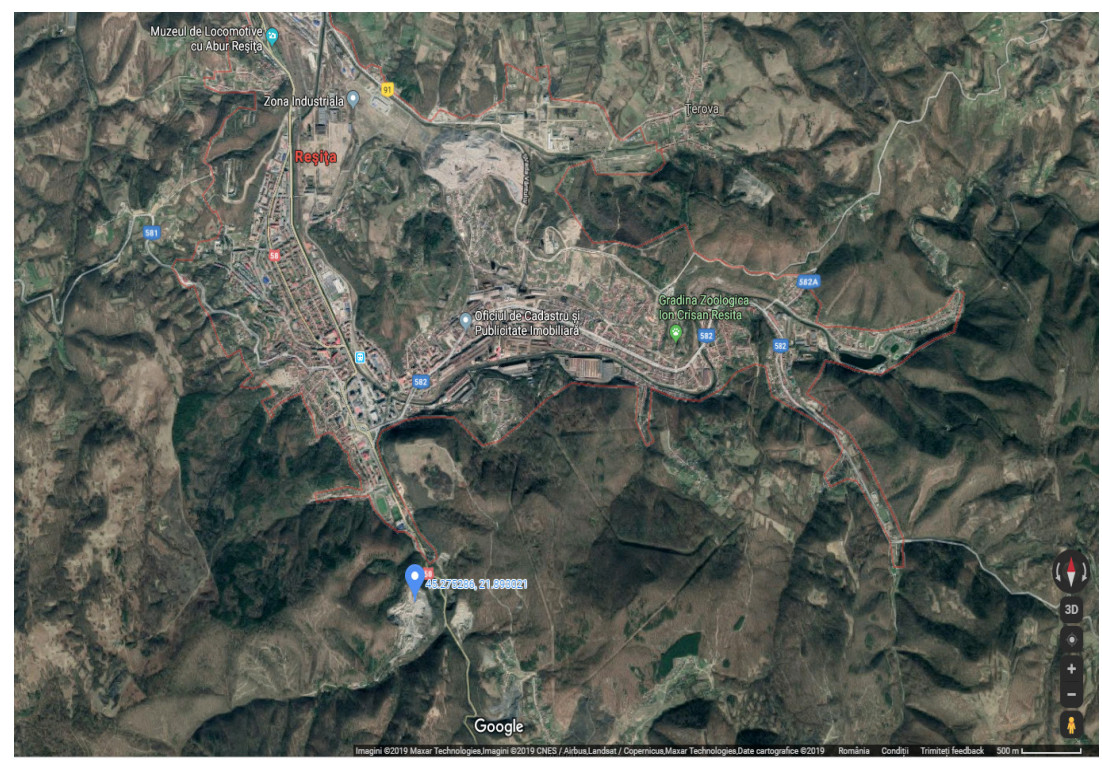

Figure 2. Localization of Doman Quarry - Reșița 


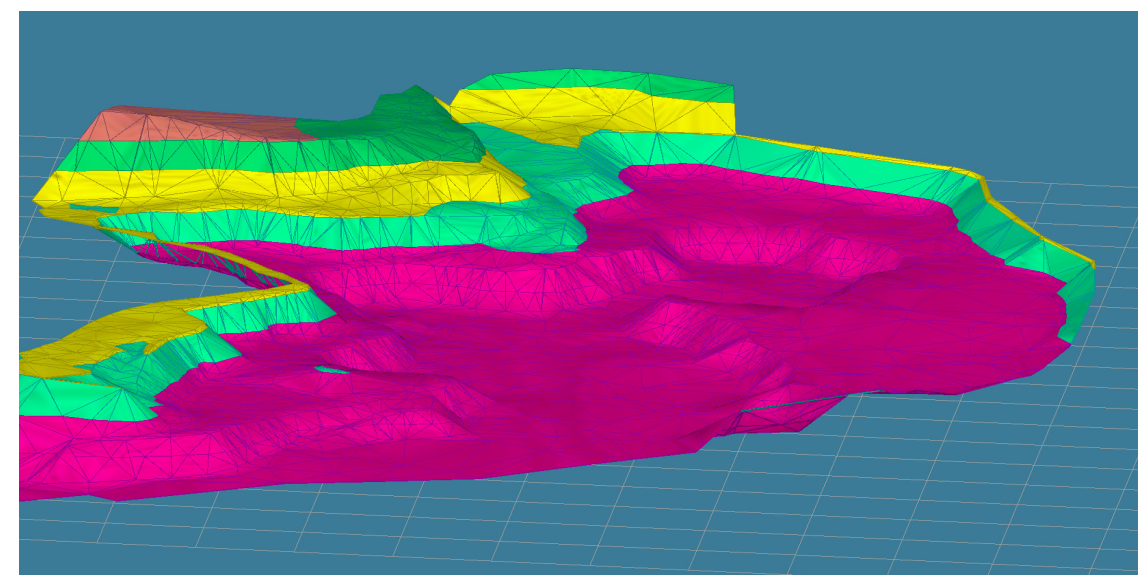

Figure 3. Doman Quarry - 3D horizontal descending operating steps

The exploitation of the DOMAN-REȘITTA deposit was performed by the method of "horizontal descending steps" (Fig. 3).

The exploitation method is the specific one for the mining exploitation in quarries, namely "mechanical blasting with the help of explosives after the drilling-blasting operations", characteristic for the surface exploitation of homogeneous deposits of useful rocks, developed at the level of the land with a low sterile/useful ratio (Dragomir et al, 2012, Farcaș et al, 2016).

The choice of the method of exploitation for the DOMAN - REŞIŢA limestone deposit has been made taking into account:

- the configuration of the deposit, its arrangement; - geological and morphological conditions;

- deposit thickness;

- tailings thickness;

- the quality of the deposit;

- maximum extraction depth;

- the characteristics and productivity of the machines;

- safety in execution.

The exploitation method used, ensured:

- high productivity,

- the rational exploitation of the deposit,

- safety from the execution point of view,

- optimal possibilities for environmental recovery,

- the possibility of quickly attacking several extraction fronts.

The determination of the volumes in the explotation of the deposits is an autonomous procedure compared to other works of engineering character in fact it represents a purpose in itself which requires the collection, processing and interpretation of geospatial data (Popescu G. et al, 2016, Sălăgean et al, 2016, Solcan et al, 2019). Basically, a volume of material discovered or exploited is calculated with reference to a period of time, based on the calculation being information taken in situ, currently processed with the help of specialized software programs. One of the methods used for the volumetric calculation is the prism method, TopoLT, mainly used, being the basis of most computing software programs (Fig. 4).

The method involves a division into triangles or elementary rectangles, which constitute the basis for the infinity of prisms that will represent the studied field (Manu et al, 2014). Volume $\boldsymbol{V}_{\boldsymbol{i}}$ of a straight triangular prism is calculated from the projection surface, the magenta area is shown on the top left (Fig. 4) and the centers of weight of the triangles of the two surfaces defining the volume, located at a distance $\mathrm{D}_{i}$ one from the the other (1).

$$
V_{i}=A_{i}^{*} D_{i}
$$

Where: $A_{i}=\frac{l^{2}+\sqrt{3}}{4}$

And the total volume between two surfaces is given by the sum of all the volumes related to the right prisms in the area taken in the studio (3).

$$
V=\sum_{i=1}^{n} V_{i}
$$



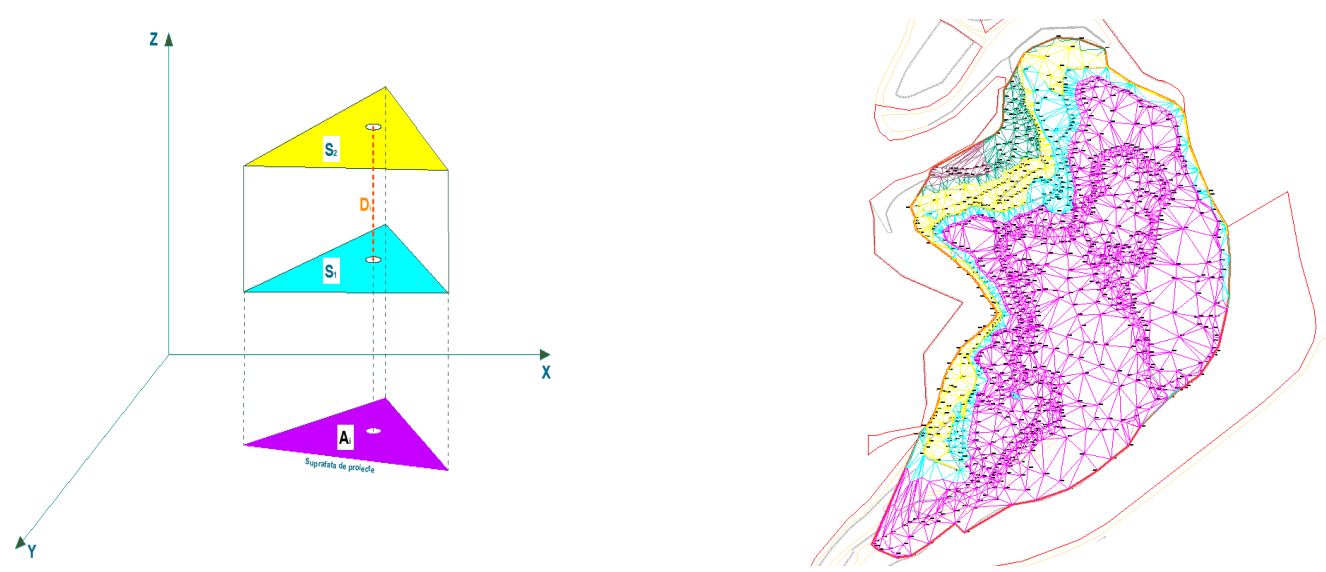

Figure 4. The principle of volume determination of a right triangular prism (left) and the network of triangles (right)

\section{Results and discussion}

Measurements were performed using the G.N.S.S. technology, revealing the location and geometrical shape of each existing operating front in the perimeter of the mining surface (Tab.1) .
The points of interest were for the working front, slope up, slope down, quota points for the upper part of the step, and for the lower part (Fig. $5)$.

Table 1. Delimitation coordinates - 1970 Stereographic coordinates

\begin{tabular}{cccccc}
\hline \multirow{2}{*}{$\begin{array}{c}\text { Point } \\
\text { No. }\end{array}$} & \multicolumn{2}{c}{ Coordinates } & Point & \multicolumn{2}{c}{ Coordinates } \\
\cline { 2 - 3 } & $\mathbf{X}$ & $\mathbf{Y}$ & $\mathbf{N o}$ & $\mathbf{X}$ & $\mathbf{Y}$ \\
\hline 1 & $424.668,904$ & 255.963 .127 & 9 & $423.685,870$ & $256.098,350$ \\
\hline 2 & $424.670,99$ & $256.400,00$ & 10 & $423.612,868$ & $215.433,835$ \\
\hline 3 & 424.600 .00 & 256.470 .00 & 11 & $423.845,091$ & $255.395,350$ \\
\hline 4 & $424.400,00$ & $256.520,00$ & 12 & $423.740,790$ & $255.980,929$ \\
\hline 5 & $424.400,00$ & 256.590 .00 & 13 & $423.687,304$ & 255.989 .277 \\
\hline 6 & $424.200,00$ & $256.600,00$ & 14 & $433,935,989$ & $256.182,918$ \\
\hline 7 & $424.050,00$ & $256.535,00$ & 15 & $424.305,904$ & $256.154,303$ \\
\hline 8 & 423.805 .813 & $256.280,721$ & 16 & $424.543,949$ & 255.958 .898 \\
\hline
\end{tabular}

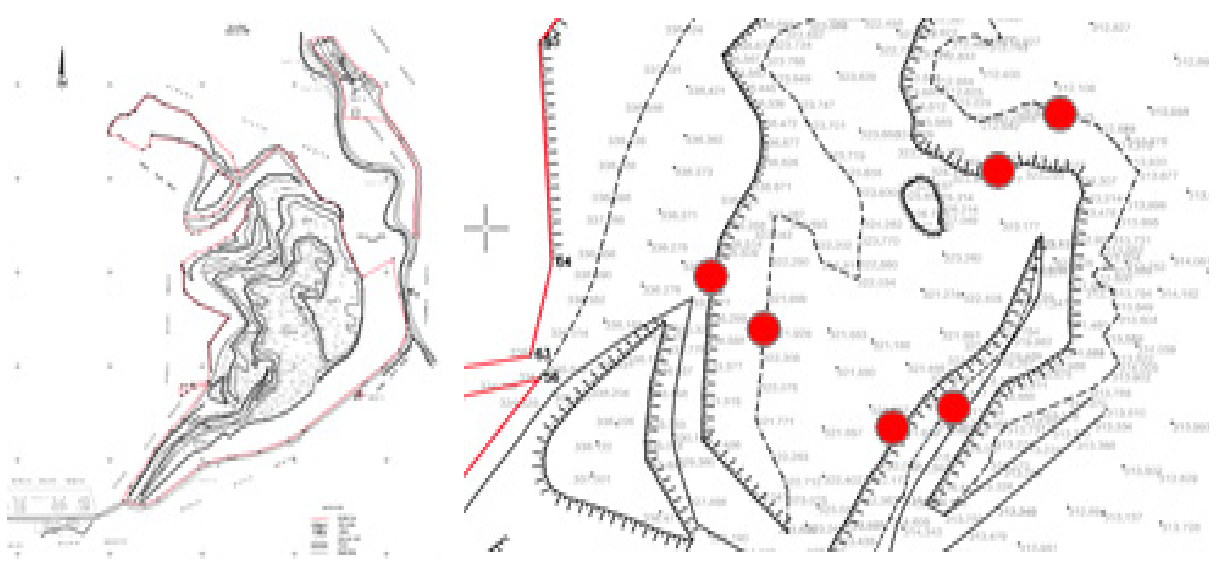

Figure 5. The points of interest were for the working front 


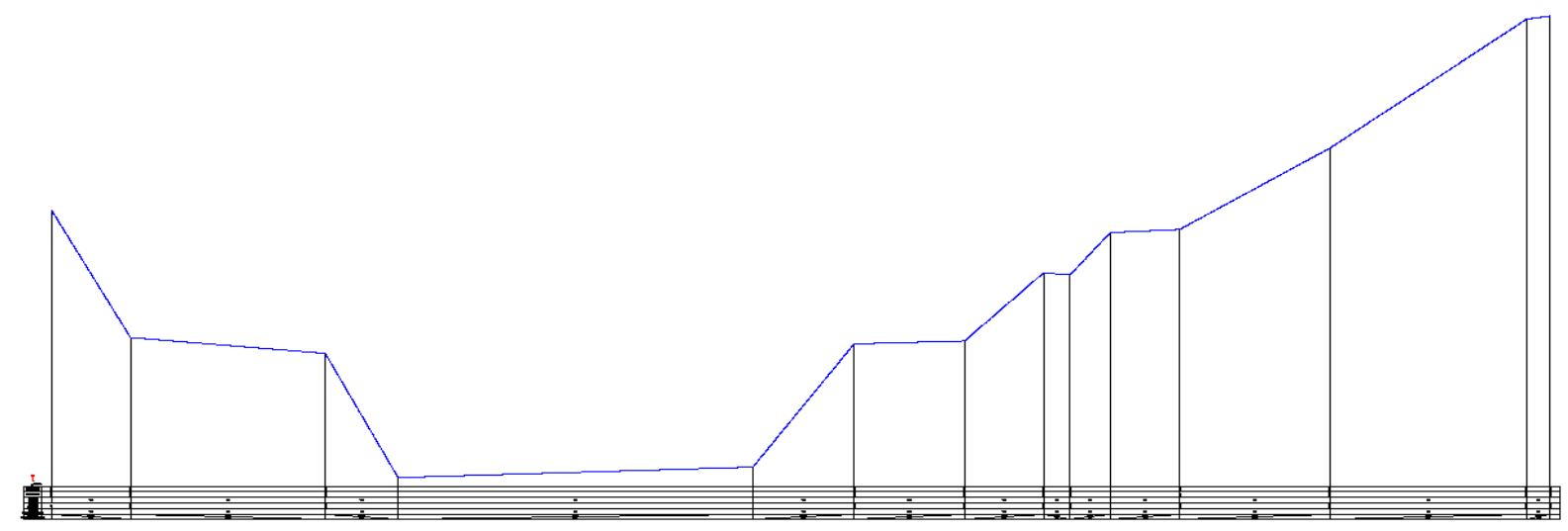

Figure 6. Operating steps - transverse profile

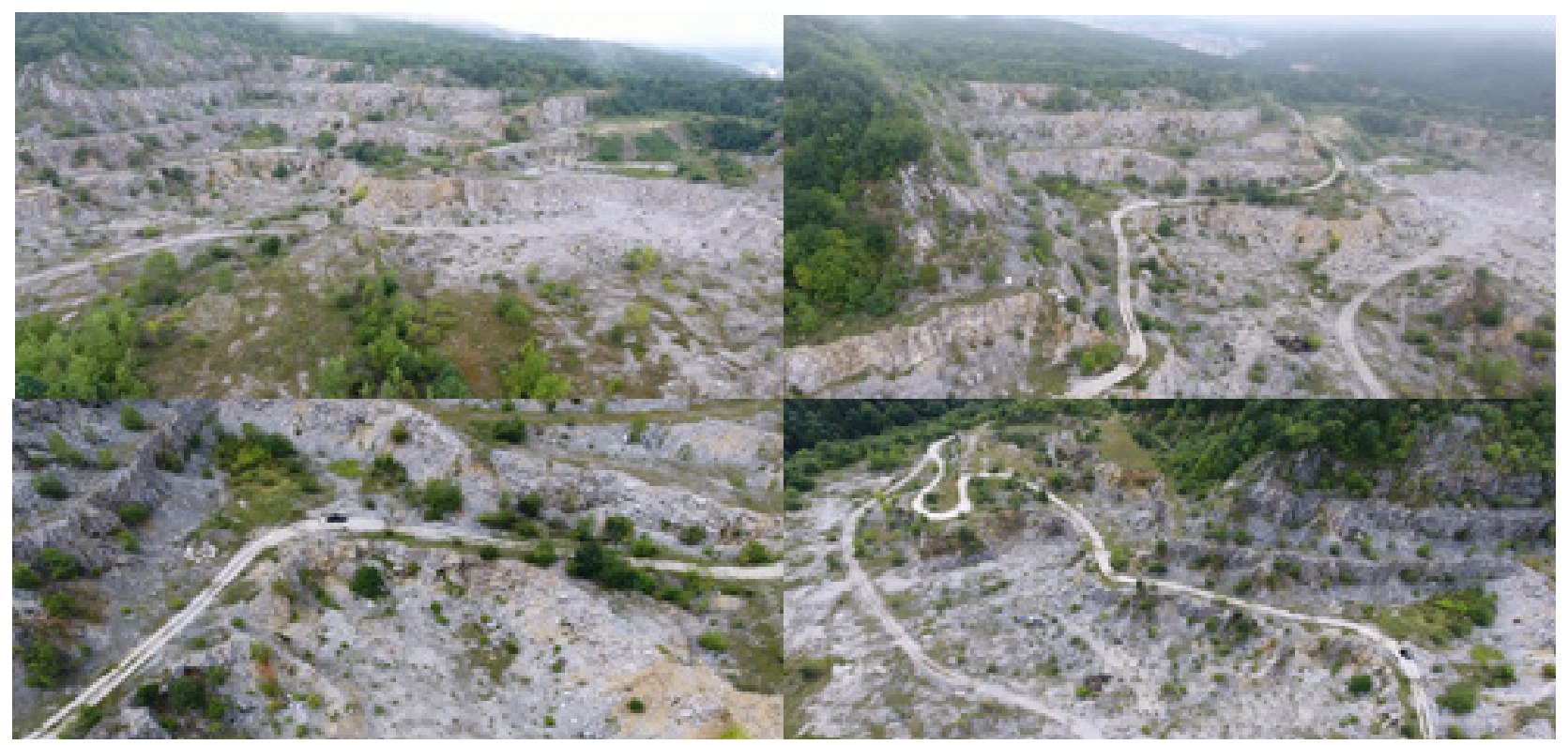

Figure 7. Surface Mining - Doman Quarry

As a result of the exploitation works carried out, within the deposit 4 operating stages are outlined (Fig. 6), with the following technical characteristics:

step IV: upper elevation: +352 to $+356 \mathrm{~m}$

- base elevation: +343 to $+345 \mathrm{~m}$

- the height of the step: $11-13 \mathrm{~m}$

- slope angle: $85^{\circ}$

- working bern width: $10-15 \mathrm{~m}$

- length of the work front: $100 \mathrm{~m}$

step III: upper elevation: +343 to $+345 \mathrm{~m}$

- base height: +332 to $+336 \mathrm{~m}$

- the height of the step: $11-13 \mathrm{~m}$

- slope angle: $85^{\circ}$
- width of working berm: 15-20 m

- length of the work front: $150 \mathrm{~m}$

step II: upper elevation: +332 to $+336 \mathrm{~m}$

- base height: +323 to $+326 \mathrm{~m}$

- step height: 9-13 m

- working berm width: $15-25 \mathrm{~m}$

- slope angle: $80^{\circ}$

- length of the work front: $130 \mathrm{~m}$

step I: upper elevation: +323 to $+326 \mathrm{~m}$

- base height: +312 to $+315 \mathrm{~m}$

- the height of the step: $11-14 \mathrm{~m}$

- slope angle: $75^{\circ}$

- working berm width: $25-35 \mathrm{~m}$

- length of the working front: $240 \mathrm{~m}$ 
The currentsurface of the quarry (horizontally) is about 79.2 ha (Fig. 8).

The industrial and construction limestone deposit from the Doman surface mining operation was approved for the first time by the end of 1989 (Fig. 9) and the chemical and physico-mechanical characteristics of the DOMAN-RESIŢA deposits were determined based on the samples collected from the research works carried out and from the quarry fronts.

Generally, the limestone has a microcrystalline to granular structure and a compact texture.

For the date of 01.01.1989, an estimated total volume of sterile material of $280,996.73 \mathrm{~m}^{3}$ was taken into account (Fig. 10). The estimated sterile material volume was the result of calculations made by the specialists in the field, referring to +365 m maximum height of the land, as well as to the minimum height of $+270 \mathrm{~m}$, which represents the quota below the quarry floor.

Based on a new calculation of useful mineral resources, carried out in 2003 (Fig. 11), by the method of "vertical geological sections", a calculation was performed that took into account the quota of the quarry base at that date - the quota of $+314.0 \mathrm{~m}$ and of the research limit in depth of limestone - quota of $+275.0 \mathrm{~m}$, the following amount of useful material exploited by category B (limestone) of $46.096 \mathrm{mc}$ was registered.

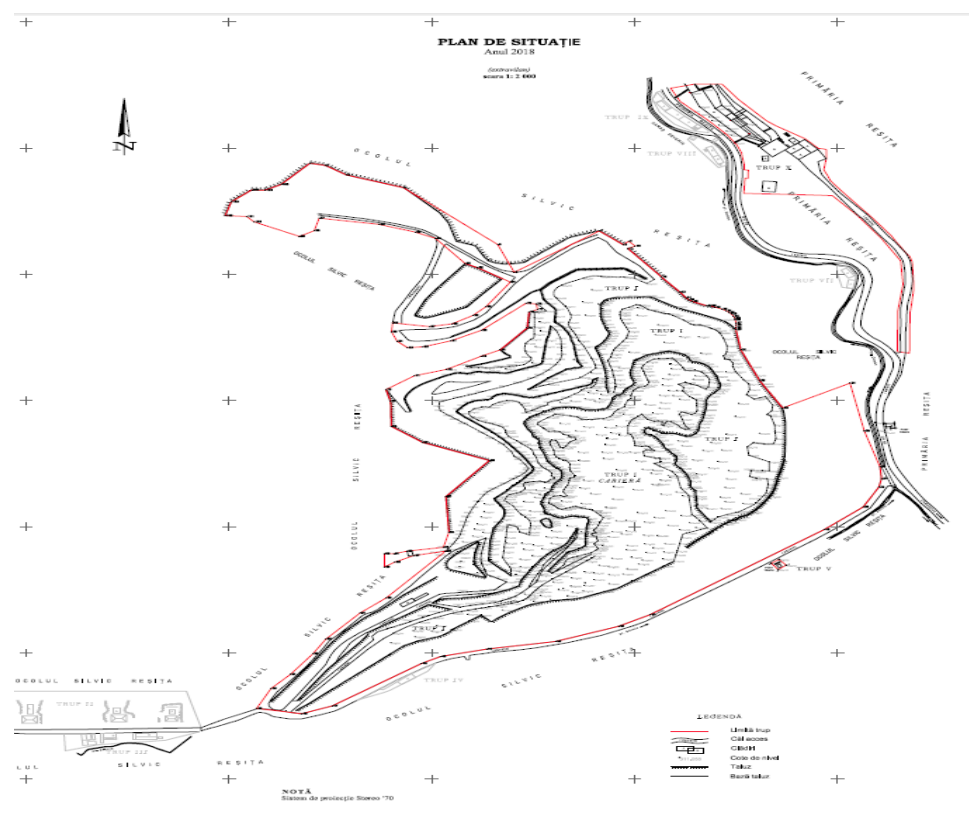

Figure 8. The updated situation plan for Doman Quarry
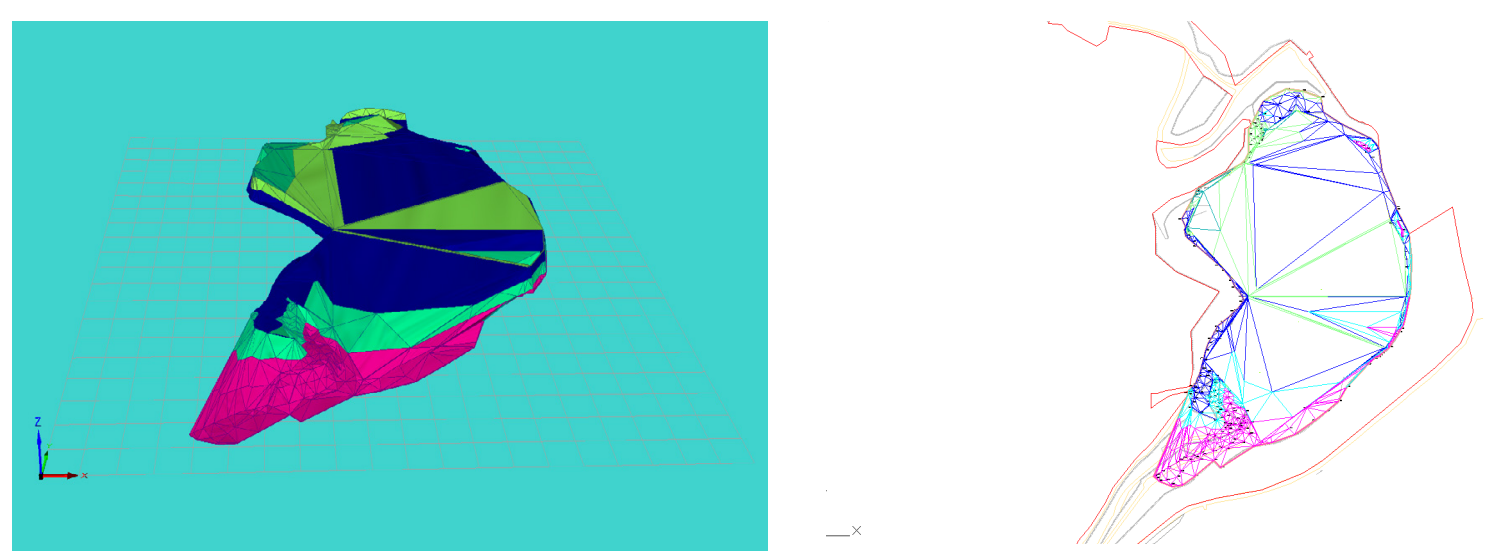

Figure 9. The digital model of the land for the Doman Mining Exploitation in 1989 

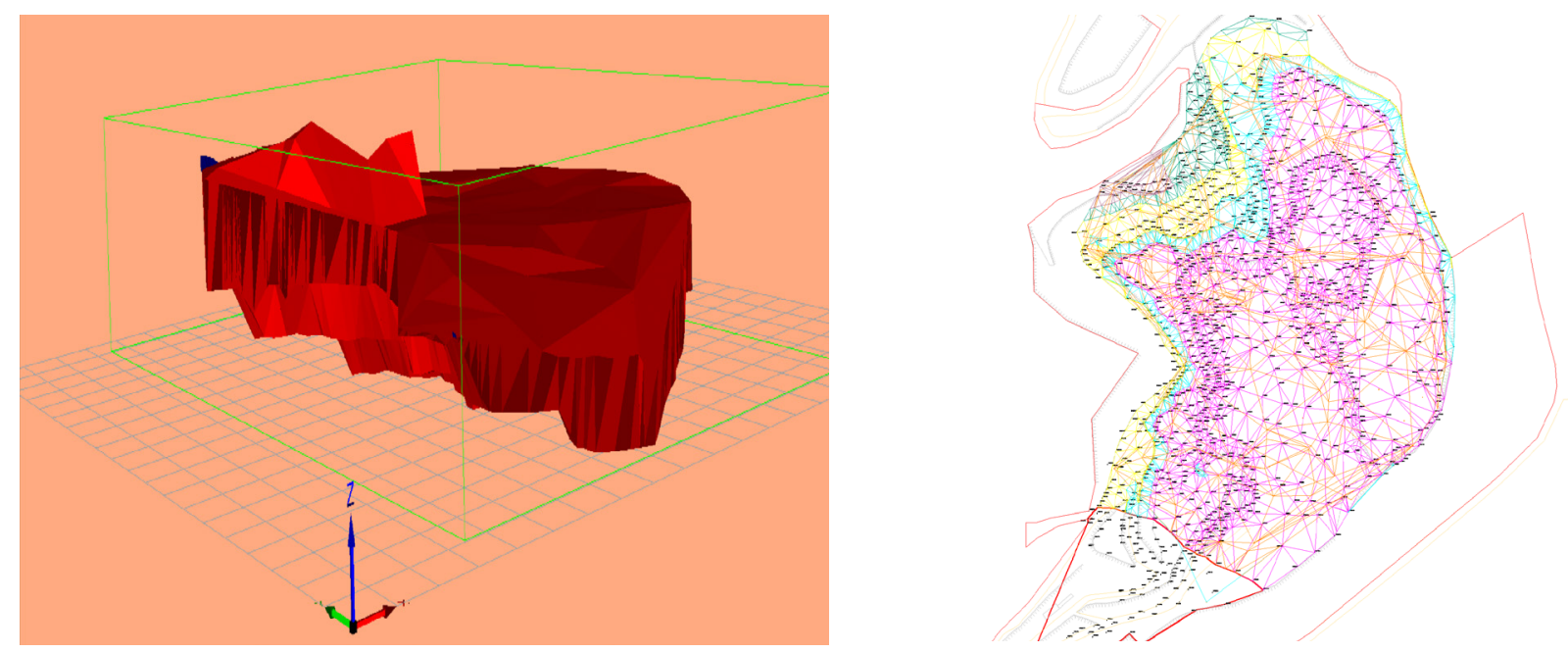

Figure 10. Total volume calculation in Doman Quarry
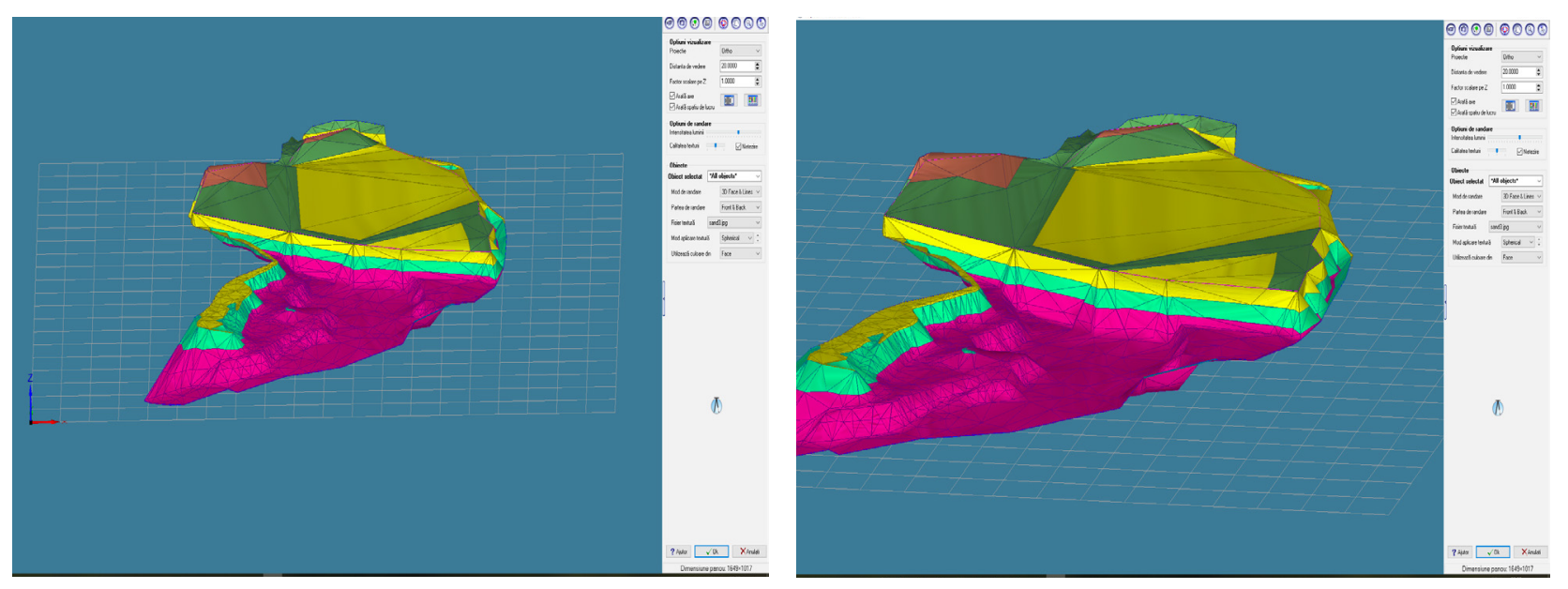

Fig. 11. Doman Quarry Configuration in 2003 - 3D Model
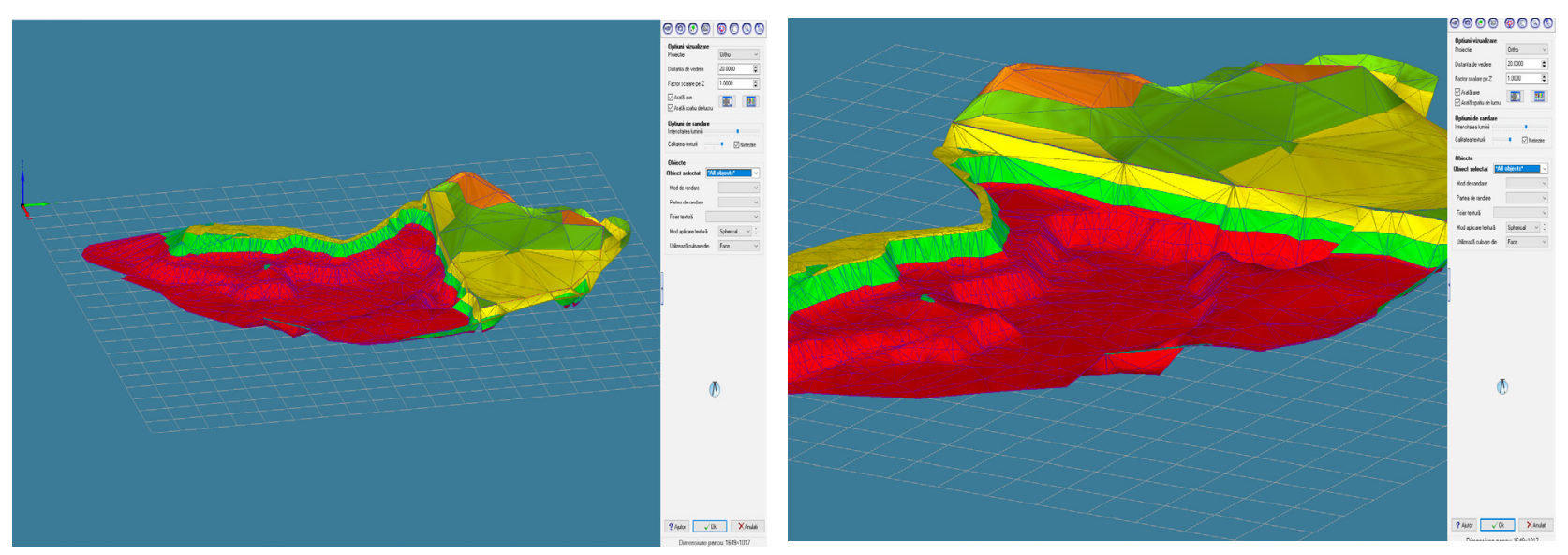

Figure 12. Doman Quarry Configuration in 2005 - 3D Model 


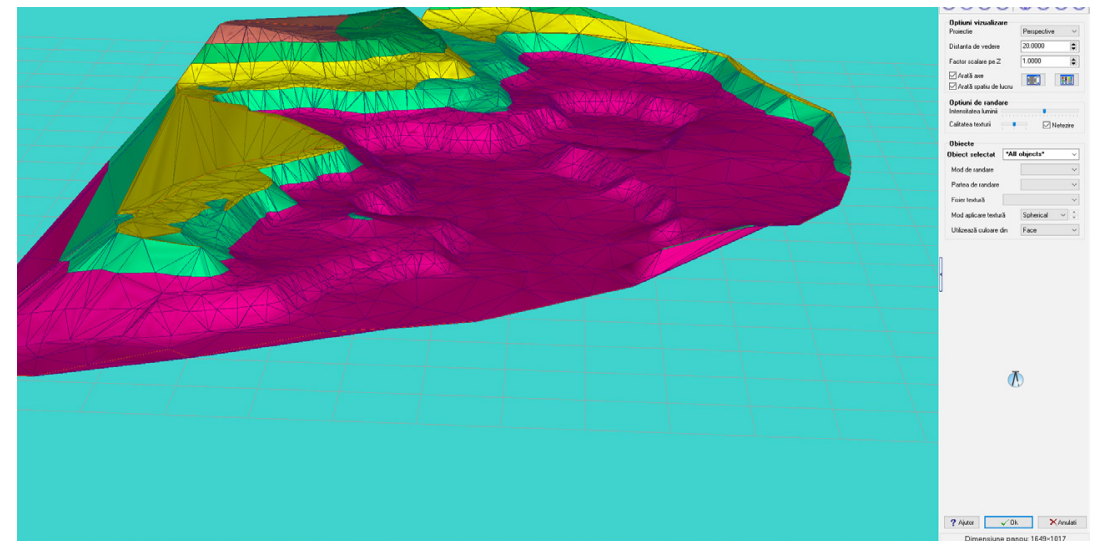

Figure 13. Doman Quarry Configuration at the end of the activity - 3D Model

The volume of useful material exploited in the period 2003 - 2005 (Fig. 12), evaluated from the category $\mathrm{B}$ balance sheet reserves, located above the quota $+314.0 \mathrm{~m}$., taking into account the coefficient of quantitative transformation $\mathrm{Kq}$ $-0.97 \%$, represents $36500 \mathrm{~m}^{3}$.

Following the last balance sheet with the annual reports on the useful material exploited in the Doman Quarry, located above the quota of $+314.0 \mathrm{~m}$ in the working fronts, in 2009 an exploited volume of $168,000 \mathrm{~m}^{3}$ was noted. Starting with 01.01.2009, the exploitation activity within the deposit has been suspended and it has not been resumed until June 2018, the renunciation of the exploitation license and the surrender of the deposit in A.N.R.M. Bucharest.

\section{Conclusion}

Regarding the software used, AutoCAD together with TopoLT, both represent the same specialized software range for topographic works, using one of the fastest volumetric calculation methods, easily programmable, containing features that help to make the terrain plans. The prism method has a number of features and options to generate a model and to edit complex, irregular surfaces with higher accuracy. These work software are useful in the area of surface mining topography, especially for the elaboration of the situational plans, in the processing of the terrain data, as well as in the creation of sketches.

\section{References}

1. Cosarca C (2003). Topografie inginereasca, Bucuresti, Matrix Rom, 157-161.

2. Dima N, Filip LO (2014). Lucrari speciale de topografie miniera, Petrosani, Universitas, ISBN 978-973-741-364-2.

3. Dragomir LO, Herbei MV (2012). Monitoring The Subsidence Phenomenon In Petrosani City Using Modern Methods And Technologies. Environmental Engineering \& Management Journal (EEMJ), Bucuresti, 11(7).

4. Farcaş R, Sălăgean T, Palamariu M, Naş S, Ortelecan M (2016). Considerations Regarding the Stability of Landmarks and Topographic Marks Placed in a Field of Salt Probes, RevCAD Journal of Geodesy and Cadastre, Alba Iulia, Romania, 45- 50.

5. Manu CS, Ciuculescu IC, Modoveanu A (2014). Calcul teresamente. Metode moderne de determinare a volumelor de sapatura si umplutura, Geomat, Iasi.

6. Păunescu V, Călin M, Manea R, Moscovici A, Sălăgean T (2017). GIS in Active Monitoring of Green Spaces, Modern Technologies for the 3rd Millenium, Oradea, Romania, ISBN 978-88-87729-41-2, 73-78.

7. Popescu CA, Smuleac A, Popescu G (2016). Modern techniques for the mapping and the delimitation of some protected Areas in timis county, Bulletin UASVM Cluj-Napoca, ISSN-L 1843-5254, 73(2): 321326.

8. Popescu G, Popescu CA, Herbei MV, Dragomir L, Herbei M (2016). The study related to the execution of a triangulation network In the dump of rovinari pit, in order to be restored to the economic circuit. Bulletin UASVM Cluj-Napoca, ISSN-L 1843-5254, 73(2): 327-332.

9. Sălăgean T, Şuba EE, Pop ID, Matei F, Deak J (2019). Determining Stockpile Volumes Using Photogrammetric Methods, Scientific Papers. 
Series E. Land Reclamation, Earth Observation \& Surveying, Environmental Engineering Bucuresti, ISSN 2285-6064, 8: 114-119.

10. Sălăgean T, Rusu T, Onose D, Farcaş R, Duda B, Sestraş $P$ (2016). The Use of Laser Scanning Technology in Land Monitoring of Mining Areas, Carpathian Journal of Earth and Environmental Sciences, Baia Mare, ISSN 1842 - 4090, 11(2): 565-573.

11.Solcan P, Sălăgean T, Șuba EE, Ilea M (2019) - Researches Regarding The Use Of G.I.S. Technologies In Modelling And Spatial Analysis of The Varatec Mining Complex, Maramures County, Scientific Papers. Series E. Land Reclamation,
Earth Observation \& Surveying, Environmental Engineering. Bucuresti, ISSN 2285-6064, 8: 148151.

12. Șuba EE, Sălăgean T, Pop I, Matei F, Deak J, Coroian I, Ficior D (2017). Using Photogrammetric UAV Measurements as Support for Classical Topographical Measurements in Order to Obtain the Topographic Plan for Urban Areas, Bulletin UASVM, ISSN 1843-52547, 4(2): 197-203.

13. Voina I, Palamariu M, Neuner I, Sălăgean T, Onose D, Ortelecan M, Moscovici AM, Călin M (2016). Digital Modeling Phenomenon of Surface Ground Movement, Bulletin UASVM Cluj-Napoca, ISSN 1843- 5254, 73(2): 342-346. 